\title{
Elephants never forget, should art museums remember too? Historic ivory collections as ambassadors for conservation education
}

\author{
Caroline Good $^{1}$ D $\cdot$ Peter Tyrrell ${ }^{1} \cdot$ Zhaomin Zhou $^{2} \cdot$ David W. Macdonald $^{1}$
}

Received: 6 July 2018 / Revised: 24 February 2019 / Accepted: 11 March 2019 / Published online: 25 March 2019 (c) The Author(s) 2019

\begin{abstract}
Ivory in art museum collections has been a contentious topic during recent years, with some parties calling for its destruction. But analysis of media reactions to the parallel strategy of burning modern ivory stockpiles may offer insight to the likely effectiveness of that course of action in museums: such burns have seemingly fallen short in sending a clear and enduring message to the intended demographics - be this consumers, dealers, poachers or traffickers. This prompts us to suggest an alternative to the destruction of museum ivory: that art museums with ivory collections take on the challenge and responsibility of imparting powerful conservation messages. This article explores the potential of ivory artworks as educational ambassadors, as well as the international reach of museums to target demographics in key ivory consumer regions such as South East Asia, and the ethical obligations of museums with ivory collections to participate in conservation education. In placing a useful lens on these currently controversial artworks, museum ivory would be endowed with a new critical relevance as educational ambassadors for contemporary conservation issues, simultaneously offering justification for the preservation and display of these historic artworks that many museums are presently reluctant to exhibit. In highlighting the potential of museum ivory as a vehicle for conservation education we highlight the need for heightened holistic collaboration across disciplines to ensure that conservation messages reach diverse audiences in novel and impactful ways.
\end{abstract}

Keywords Wildlife conservation · Art museums · Conservation education · Ivory · Elephants $\cdot$ Culture and conservation

Communicated by David Hawksworth.

This article belongs to the Topical Collection: Biodiversity exploitation and use.

This article belongs to the Topical Collection: Biodiversity appreciation and engagement.

Caroline Good

caroline.good@zoo.ox.ac.uk

1 Wildlife Conservation Research Unit, Department of Zoology, University of Oxford, Recanati-Kaplan Centre, Tubney House, Abingdon Road, Tubney OX13 5QL, UK

2 Key Laboratory of Southwest China Wildlife Resources Conservation (Ministry of Education), China West Normal University, Nanchong, China 


\section{Introduction}

On April 30, 2016, the largest ivory burn in history took place in Kenya. The event caused a dramatic spike in online, print and social media support for its message against the resurgence in poaching and the ivory trade that has seen African elephant populations plummet over the previous decade (Chase et al. 2016; Wittemyer et al. 2014). But a recent study exposed the media reaction as not only fleeting, but also failing to reach the intended global demographics of consumers, dealers, poachers and traffickers (Braczkowski et al. 2018).

In what might seem a world away from the savannahs, plains and forests that elephants inhabit, museums around the world are faced with their own ethical issue: the nowadays contentious (and frequently copious) historic elephant ivory artworks in their collections. There have been calls for the destruction of private collections of these artworks motivated by the desire to send a forceful message that ivory trade is abhorrent (IFAW 2017; Cole 2018), as well as fears that the existence of such objects provide a veneer of legality for black markets across the world (Morrison 2014). Others vehemently oppose this, labelling the proposed destruction acts of philistinism (Dodgeson 2017; Levy 2018). These impassioned perspectives are responses to the need to recognize, and right, the wrongs of history. Yet the destruction or deaccession of artefacts, as equally the whitewashing of their origins, verges on denial of, rather than learning from, the past. Hovering somewhere between these divergent poles of opinion are nervous museum curators, uneasy at the possible consequences that their ivory collections bring (Curnow 2018).

But are the preservation of elephant populations and the display of artistic ivory artefacts necessarily contradictory endeavours? Here, we explore the possibility that the answer might be no. We propose an alternative approach, one that would benefit people and elephants alike. Playing a longer and more thoughtful game would see ivory in art museum collections transformed into educational resources, with the craftsmanship of these artworks holding the unique potential to exalt the lessons of history, and share the urgent imperative to conserve and revere wild elephants today. Whether tackled from the consequentialist perspective of seeking the least worst case, or an ethical conviction to sanctify beauty and craftsmanship, this proposal investigates a more enduring and educational way to utilise these art works.

We will first discuss reconciling conservation biology with historic culture through museum education and then demonstrate the possibilities of impacting key demographics with the international reach of art museums, with an exemplary exploration of museum ivory artworks as ambassadors for conservation. What follows is a discussion on the possible receptivity and resistance from museum professionals, and an analysis of the ethical implications of displaying historic ivory. In conclusion, we discuss the issues around making this a global movement towards educated change.

\section{The edifying potential of the museum}

Long before gold and gemstones held allure, humans were drawn to the elephant's resplendent tusks (Walker 2009). Ivory came to be prized in every culture-from ancient Egypt to Mediaeval Europe, and twentieth-century America to modern Japan (Somerville 2016). Museum collections show how tusks were transformed into sensuous figurines, sacred icons, scientific instruments, pistol grips and piano keys, and how ivory was the 
material of choice because of the purity of its colour and its remarkable carving properties (Vollrath et al. 2018). But ivory's allure has come at a profound cost. And not just to elephant populations. The loss of any large animal has profound impacts on the ecosystems they dominate (e.g. Terborgh and Estes 2010). And the continued loss of earth's largest terrestrial mammal will have cascading effects on ecosystem functions, with potentially widespread ramifications for human society (Dirzo et al. 2014; Malhi et al. 2016). While history cannot be re-written, the belief that the future need not mirror the past drives many of today's elephant conservationists to work for a reduction in the demand for ivory. But as Braczkowski et al. (2018) conclude, passing on a conservation message, or indeed any thoughtful message, is a challenging and complex undertaking.

While there is undoubtedly no one-size-fits-all solution, art museums present a potential alternative outlet for this kind of message-sharing. These institutions not only contain the ivory objects that hold the history of the elephant's current status quo, but are spaces where empathy towards non-human animals has demonstrably been developed because of the opportunity they provide to learn about the individual history of animals, a critical step in the development of compassionate understanding (Young et al. 2018; Cohen and Heinecke 2018). More generally, museums have been identified as more trusted sources of scientific information than the mainstream media because they are perceived as impartial environments (Cameron 2007; Cameron et al. 2013). And with upwards of 70 million visitors worldwide crossing the threshold of the top 15 art museums alone in 2016 (Fig. 1: AECOM and TEA 2016), the reach of these institutions is substantial.

The effectiveness of educational experiences on both imparting knowledge, and crucially, changing behaviour is, however, highly variable (Moss and Esson 2013). For museums to be effective, therefore, a number of key considerations would have to take place: (1) the educational content of each institution would have to be tailored to their specific audiences and to regional conservation needs (Chang 2006); (2) conservationists would need to actively engage with art museums to generate informed, up-to-date, meaningful messages (Bride 2006; Wyner and Desalle 2010); and (3) when presenting to new audiences, care

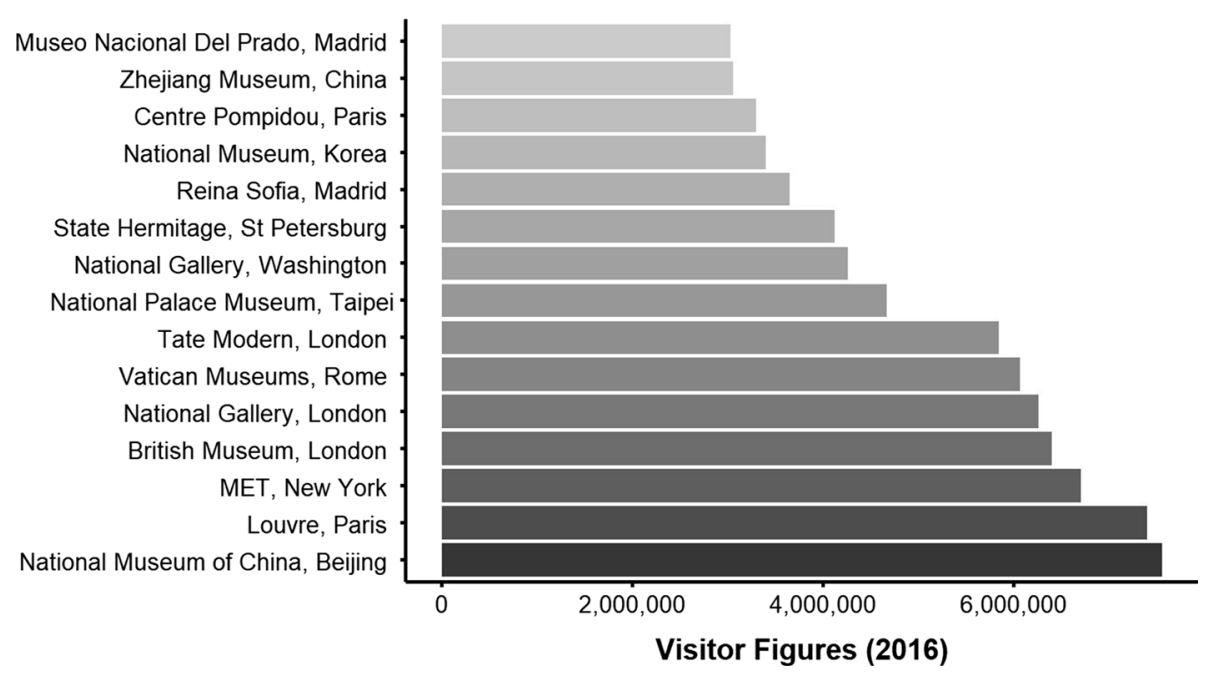

Fig. 1 The top fifteen most visited art museums globally in 2016 and the annual numbers of visitors, with data from AECOM \& TEA (2016) 
would have be taken to ensure the uptake of the intended message is not hindered by a lack of local and national focus (Brewer 2001). Therefore, the educational process needs not only to be carefully thought out, but also its impacts monitored.

Therefore if museums were to use ivory as a tool to educate the broader public there are questions that would have to be asked. What audience(s) are being targeted? What message(s) need to get across? How is the message best delivered? Even if a target demographic is 'educated', will this kind of exposure catalyse change? There will be multiple answers to these questions (Chang 2006; Carter 2017), and lessons can be learned from the widespread adoption of conservation-education in zoos and aquariums, whose environmental messages reach 700 million visitors a year worldwide (Gusset and Dick 2011).

One American institution already pioneering one such approach is the Smithsonian, which has nineteen museums under its jurisdiction. They have established an Ivory Task Force to confront these complex challenges. The institution has multiple interests in ivory, from housing and displaying many historic art and culture objects, to working with law enforcement agencies in the forensic analysis of the material, and conducting field projects in conservation biology (Cole 2018). Following former President Barrack Obama's Executive Order Combatting Wildlife Trafficking in 2014, the federal government responded to the global crisis in a number of ways, and the Smithsonian worked with the Office of the Deputy Undersecretary for Collections and Interdisciplinary Support (DUSCIS) to create relevant educational opportunities (Kurin and Ashe 2018).

Building on this, and spurred on by strict regulations implemented in May 2016 that made it illegal to import any ivory into the U.S., a group of Smithsonian scholars and museum peers came together to produce an issue of Curator: The Museum Journal exclusively focused on ivory. The contributors grapple with the need for more effective measures to preserve elephants while also protecting and treasuring ivory in historical contexts. Director Emerita Johnnetta Betsch Cole, for example, examines the issue through the lens of the National Museum of African Art which has strategically used historic ivory within exhibitions to inspire dialogue about current policy and conservation challenges (Cole 2018). Outside of the Smithsonian, contributors from the Palazzo Madama-Museo Civic' d'Arte Antica, Turin (Castranova and La Ferla 2018), and the Walters Art Museum, Baltimore (Lauffenburger and Drayman-Weisser 2018) also detail successful education programmes that advocate for both art and animal conservation using the ivory in their collections.

\section{A global education: targeting key demographics}

The promotion of elephant conservation-education programmes in these art museums is encouraging. But reaching key demographics means engagement with, and co-operation from, a much broader spectrum of museums and institutions with historic ivory collections. Countries that have recently taken major measures to combat ivory trade such as the US, UK, and China, are home to some of the most visited art museums worldwide (Fig. 1), with extensive ivory collections linked to their long national history of involvement in the trade of the material. One example is the National Museum of China (NMC), Beijing, that topped the global visitor list in 2016 (AECOM and TEA 2016) and has over 1400 ivory art objects in their digitized collection. China has a long history of master ivory carvers, the works of which display staggering skill and artistry. Simultaneously, a large proportion of 
today's ivory consumer demographic is from Asia, with some experts reporting up to $70 \%$ of elephant ivory being transported to China alone (Vigne and Martin 2017).

A 2017 Environmental Investigation Agency report revealed the UK as the largest global exporter of ivory to Hong Kong and China, distributing more legal ivory (defined in 2017 as antique ivory created prior to 1947) than any other country between 2010 and 2015 (EIA 2017). In April 2018, the UK government imposed a strict ban on ivory trade, with narrow exemptions, in an attempt to tackle this issue. The potential impact of this ban has been under considerable scrutiny (see for example: Levy 2018; Kramer et al. 2017; and Lemieux and Clarke 2009). If UK museums with ivory collections worked with the government, ground-level education on the reality of illegal wildlife trafficking, as well as the extensive role the country has played in ivory trade throughout recent centuries, could be brought into view. One example is the British Museum (BM), London, an institution that has amongst the highest footfall of museum visitors in the world. A search for "ivory" in the BM's digitized collection brings up over 13,000 ivory objects, from pistols and swords, to clocks and cabinets. With corpora of this magnitude, consider the impact of a policy stipulation along the lines that art museums be required to place beside every ivory artwork a number: the percentage of elephants lost from that population since it was carved.

In January 2018, a Chinese ban on ivory trade was also implemented. But with China having the world's largest human population, fastest growing wealth, and a history-long fascination for the material, the black-market trade is expected to continue so long as consumer demand remains (Stiles et al. 2016; Jennings 2018). The market is understood to be largely driven by a desire for inexpensive jewellery and religious trinkets: purchases motivated by increasing trends in mass-culture where ownership is perceived as status symbol rather than incentivised by connoisseurial delight for ivory carving craftsmanship (Vigne and Martin 2017).

Chinese government policy set out in 2016, which formed the foundation for the nationwide trading ban in 2018, denies the commercial value of new ivory and its products but simultaneously venerates the cultural value of historic ivory artworks (Notice of the General Office of the State Council 2016). Written into the policy are directives for ensuring the preservation of the intangible cultural heritage of ivory carvings and master carvers, as well as the vigorous education of the public on conservation issues. The policy encourages simultaneous action on several fronts: that ivory carving masters engage in art restoration work in museums; that non-profit social and cultural groups and industry associations integrate existing resources to form ivory carving studios for the research and inheritance of ivory carving techniques; and that the conservation of diverse ecosystems is resolutely advocated to guide the public to consciously resist the illegal trading of ivory and create a positive social environment for the protection of wildlife and other wild animals and plants.

Art museum conservation education programmes using historic ivory collections could be a way of reaching a broad cross-section of China's consumers. Chinese government policy indicates that museums would be receptive, even duty-bound, to streamline the two components of implementing conservation education and safeguarding ivory's cultural heritage under one institutional roof, endowing their historic ivory artworks with conservation value. And one thing is certain, the adoption of such a policy in museums would reach an extensive audience. Throughout China, museum visitor figures have grown at an approximate rate of 55\% per year between 2006 and 2015, with the National Bureau of Statistics of China recording upwards of 781 million museum visitors in 2015 (Daxue Consulting 2017). What's more, in 2016, 135 million Chinese tourists travelled abroad, with 820,000 


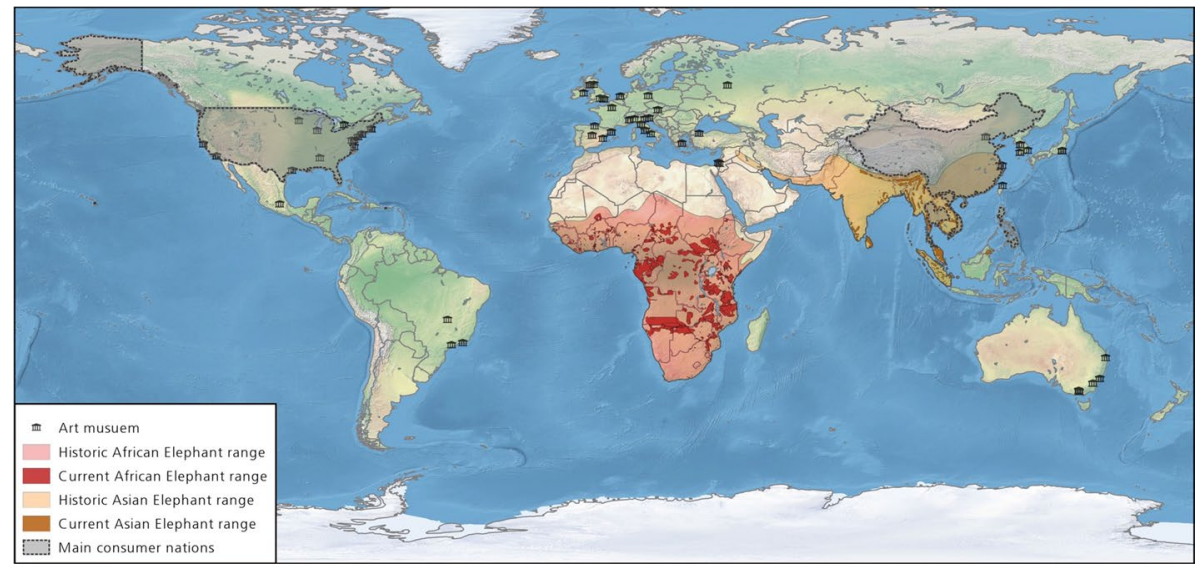

Fig. 2 World map displaying the current and historical range of both African (Loxodonta africana and Asian elephants (Elephas maximus): current distribution data from IUCN (2018), historical distribution data adapted from Jepson and Canney (2003) and de Boer et al. (2013). Art Museums are of one hundred of the most well-known art museums found during a search of the grey literature, this may not be a representative sample of art museums in China and the far east. The top five ivory consuming nations (China, Vietnam, Thailand, USA and Phillipines) are shown, as identified by National Geographic and Globescan (2015)

Chinese visitors attending the Louvre Museum, Paris, and 36\% of Chinese tourists to the U.S visiting an American Museum during their trip (Daxue Consulting 2017).

These statistics serve as a reminder that the international reach of museums should not be under-estimated (Fig. 2). In the financial year up to June 2017, the website of the Metropolitan Museum of Art (MMA), New York, received a total of 31 million site visits, $35 \%$ of which were international (Met Museum Press 2017). The pages of the museum's digitised collection alone drew 8.3 million, where over 7000 ivory objects are detailed and social media facilitates story-sharing of individual artworks with global audiences. The Met 360 Project - which presents videos on Facebook that allow viewers to explore iconic objects and spaces in the museum from never-before-seen perspectives-proved enormously popular in the financial year up to June 2017, garnering 11.5 million views and 451,000 interactions, including 220,000 comments. Sixty-seven percent of the MMA's Facebook followers were international (Met Museum Press 2017).

Likewise, the BM has a YouTube channel with over 90,000 subscribers, a Twitter with 1.95 million followers, and its Instagram Stories - a combination of images and video that last $24 \mathrm{~h}$-received an average 30,000 views in the financial year up to June 2017 (British Museum Annual Reports and Accounts 2016-2017). As the website and social media figures for these museums evidence, audiences are increasingly international. But this is not enough. Braczkowski et al.'s analysis of the ivory burn media coverage found that the majority of online news on the topic came from the US ( $81 \%$ of articles). This serves as a reminder that in making any moment a movement, globalism needs to be embraced and neo-colonialism must be avoided. Museum objects, with their personal histories and pertinent relevance to today's issues, can deliver the message to target audiences in a way the ivory burn fell short.

In the MMA and BM collections are two near-identical ivory pendant masks from the Kingdom of Benin (present day Nigeria) that provide an example of how the story of a 
Fig. 3 Left: Queen Mother Pendant Mask: Iyoba. 16th century. Ivory, iron and copper. $23.8 \times 12.7 \times 8.3 \mathrm{~cm}$. Metropolitan Museum of Art, New York [Image: Public Domain]. Right: Benin Ivory. 16th century. Ivory, iron and bronze. $24.5 \times 12.5 \times 6 \mathrm{~cm}$. British Museum, London [Image: Public Domain]

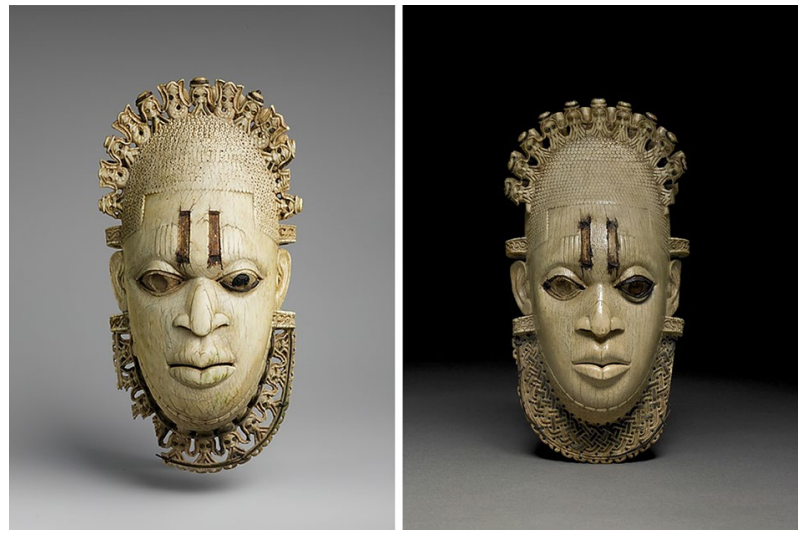

single object can be a mouthpiece for conservation education (Fig. 3). Believed to be a sixteenth century portrait of the then oba's mother, Iyoba, the haunting face is framed with a mane of Portuguese merchants interspersed with stylised mudfish. The ivory of the masks, and their miniature merchant motifs, make reference to the extraordinary wealth generated in the Benin kingdom through trade of elephant tusks and human slaves with Portugal.

Conjuring the tangled histories of poaching, slavery, and colonialism, these masks also register a detrimental turning point in the history of the African elephant: when the indigenous Benin people gained not only new economic incentives but also access to European firearms. The latter commenced a new level of over-exploitation that precipitated the widespread slaughter of Nigerian elephant herds (Walker 2009). What museum visitors may be surprised to learn, is that not only has this butchery not ceased, but worse, in the last 50 years large scale poaching and ivory trade has become the primary driver for the rapid decline in African elephant numbers (Milner-Gulland and Beddington 1993), and in the last decade, between twenty- and thirty-thousand African elephants have been killed each year for their ivory (Wittemyer et al. 2014). Nigeria, once home to vast herds of elephants, has probably less than 500 remaining (Thouless et al. 2016).

Within the museum environment - that in this digital era extends beyond its institutional walls-ivory artworks such as these have the potential to become ambassadorial mouthpieces for elephants. The closure of domestic ivory markets worldwide requires support and encouragement by the global community (Wittemyer 2016; Zhou et al. 2018). The colossal public engagement, international ubiquity, and proven influence of art museums suggest they have the ability to reach target demographics and catalyze pro-environmental thought as facilitators of conservation education (Cameron et al. 2013). In other words, they have the potential to impact audiences in a manner and on a scale that media 'moments' are failing to harness. 


\section{Receptivity and ethics}

How receptive might art museums be to making ivory education part of their policy? The seventeen articles in the Curator special issue suggest that cooperation might not be uniformly forthcoming. Perhaps unsurprisingly, the authors concerned with natural history museums appeared the most motivated in creating greater dialogue between conservationists and museum professionals to implement better use of museum ivory for educating the public about both its history and current threats to elephant populations (Dorfman 2018; Scanlon 2018; Kurin and Ashe 2018). Voices from the art world were less unified. The greatest resistance came from those deeming the connection of antique ivory and the plight of today's elephant both non-existent and irrelevant (Levy 2018). Jens Ludwig Burk questions why the history of the elephant should be the chosen story for an ivory object in an art museum, when there are so many other narratives at play (Burk 2018). Kathy Curnow also warns that heightened awareness could also mean that some museum visitors with little sense of ivory's cultural context in Africa may unfairly blame past African artists for today's near-extinction of elephants (Curnow 2018).

While there are no representatives of Asian institutions in the Curator special issue, looking across the Pacific, a similar pattern emerges. The National Zoological Museum of China and Beijing Museum of Natural History both provide oral explanations and display boards for conservation education alongside their exhibits of endangered animals, but art museums with ivory collections have not yet established the same edifying dialogue with the public. The observations of Curnow and Burke go some way in explaining this global fissure between ecological reality and historic artwork displays. Both authors point to the pertinent issue of contextualisation: if you have an ivory carving on display in a natural history museum, its context in the conservation narrative can be comprehended with adequate ease, whereas an ivory carving in an art museum may require considerably greater explanation. This nervousness might best be met by ensuring art museum curators were fully supported by relevant, trans-disciplinary expertise as they navigate the ethical quagmire of their ivory collections, as well as providing evidence-based research of how receptive art museum audiences might be to encountering this kind of information.

Ivory's unique link between humanity's difficult past and earth's perilous present makes it a powerful material for conservation education. From climate change and colonialism, to the history of weapons and instruments, it is a material that is deeply embedded in the story of humanity. But these are not the only stories these ivory artworks have to tell. Museum objects are, by nature, imbued with multiple different values. Decisions about what values to include and how to present them are ethical issues for museums because they influence the public's perception (Gazi 2014). How then can museums deal with the ethical issues surrounding the display of ivory? And why is now the time that the story of the elephant should be the dominant narrative of ivory artworks?

The ethics surrounding museum displays are pre-eminently about values, and ethical questions often arise when multiple values compete (Edson 2009). Ethics vary in time, place, and culture (Gazi 2014). If the notion of 'value' is at least partly culturally specific, no particular ethical system may be said to be absolutely right or wrong, and ethical questions could be understood as conflicts in cultural values (Goldstein and Kintigh 1990). One recent example saw an online petition gather over 8000 signatures to urge the MMA to rethink its decision to show Balthus' "Thérèse Dreaming" (1938), a painting which depicts a young girl in a suggestive pose that leaves her underwear visible. At the time of the petition, an incursion of sexual assault allegations was making headlines every day in the US media. The petition accused the museum of "romanticizing voyeurism and the objectification of 
children." The painting was not withdrawn. The museum justified its decision on the grounds that moments like this provide an opportunity for conversations, and the visual arts provide a significant forum for reflection, encouraging the continuing evolution of existing culture (Libbey 2017). Though the painting remains, the furore around it demonstrates how, even within one culture, ethics clash and change as the needs and values of society, and museums, shift. What was considered acceptable in the past may not be now or in the future.

The ethics of displaying human remains is a similarly contentious issue (Kilmister 2003), and holds some parallels to displaying ivory. Many codes of ethics urge museums to consider such material with great caution and respect for the beliefs of the cultures involved (examples include ICOM 2004 and Museums Association (MA) 2008). If similar guidelines were applied to elephant parts, it would become the ethical duty of a museum to sensitively inform visitors about the contextual reality of an ivory artwork's origin and inception, and indeed of the elephant's story as well as the human narrative that surrounds it.

In June 2018, Hartwig Fischer, the BM director, defended a controversial acquisition of more than 500 historic Chinese ivories, as public attitudes towards the modern-day trade in ivory hardened. Fischer stated that the museum "unreservedly endorsed" the public campaign to ban the ivory trade but added that historical works of high cultural value needed to be preserved and made available for public display and scholarly study. "These ivories [made] in the last centuries or millennia... do not save any elephants' lives today." (British Museum Annual Review 2017-2018). But if the BM had a public facing conservation education policy for their ivory displays, not only might acquisitions of this kind be better defended, but conservation awareness could be promoted in the process and some elephants lives today could possibly be saved as a result.

Displaying controversial artworks will doubtless divide museum audiences but ultimately make them think hard about the subject in hand. By providing carefully considered context that conveys different voices and perspectives, museums can stimulate conversation and education (Cole 2018). With the present alternative scenarios seeing ivory artworks kept out of sight in museum store-rooms, and ivory poaching diminishing elephant populations in some areas at staggering rates, it is timely for museums to adopt an ethical conservation-education approach to both utilise and safeguard their collections, and deliver a new narrative that promotes the dignity of the elephant.

Removing ivory artworks from public view may provide short-term relief from their provocation. But what does eliminating one beautiful thing in the attempt to save another accomplish? First, it may not be necessary insofar as the values of historic art and, in the case of museum ivory, living elephants may be incommensurable. Furthermore, it may not work, ending up as a grand, well-intentioned, but fruitless gesture, detracting from the real problem for elephant conservation: that of securing wild populations in Africa and Asia, and reducing illegal trade in ivory. Understanding the millennia long exploitation of elephants means that the joy and admiration that ivory in museums may arouse is tarnished with poignancy. But by creating an ethical dialogue around these works that addresses this history and confronts the impacts of the human past, the equally treacherous pitfall of historical denial is avoided. After all, many museums successfully exhibit displays about slavery, racism, and genocide. In fact, there are entire museums dedicated to these matters around the world (e.g. Kigali Genocide Memorial, U.S. Holocaust Museum, Washington D.C., International Slavery Museum, Liverpool, and Apartheid Museum, Johannesburg). These museums are not advocating their namesake issues. Quite the opposite: they are confronting them, and educating the wider public about their existence and their importance, both in historic and cultural recognition and remembrance, and for a more informed future that hopes to learn from the mistakes of the past. 


\section{Conclusion: message to movement}

While debate and disagreement around the trade in ivory are unlikely to resolve any time soon (Biggs et al. 2017), museums today are mandated to strive to further educate audiences about current events as well as uncomfortable histories that continue to impact imperilled wildlife. If museum ivory is cloistered or obliterated to attempt a kind of cultural cleansing of the slate of history, not only will records of the elephant's plight over thousands of years be erased with it, but also the opportunities these artworks provide to inform and educate about global issues impacting the planet today. After all, society is the custodian of both cultural heritage and wild animals.

Ivory in museums should not be hidden from view. Yet it must also be placed in its true context, past and present. It is both lazy and immoral to ignore the brutal way its material was gathered and disconnect it from what is happening today. It is no longer the role of museums merely to preserve the past. As Young et al. (2018) assert, they have a responsibility to be educational institutions rooted in the present that reach the broader public and facilitate discussions about societal values and changing mind-sets. If museum professionals reflect carefully and responsibly, and conservation experts establish a supporting role, the intrinsic beauty, awe-inspiring craftsmanship, and the stories of ivory art work's inception and value have the potential to deliver an educational conservation message that is required worldwide.

While there is undoubtedly no one-size-fits-all solution, a transdisciplinary approach is needed, while simultaneously harnessing the potential of the strong emotional reactions that 'moments' like the ivory burn create. The potential for art museums to impart conservation messages, and not just those focused on ivory and elephants, should be something that museum and conservation professionals explore as a novel method for conservation education and outreach, and this approach underscores the need for heightened collaboration between disciplines to rethink how conservation messages can reach broader audiences in new and meaningful ways.

Acknowledgements We are deeply indebted for the enthusiasm and insight of Keith Somerville, Lucy Vigne, and John Vucetich who kindly offered their expertise at various stages of the manuscript's development. We would also like to thank Dawn Burnham for numerous useful discussions. David W. Macdonald is grateful to Xa Sturgis of the Ashmolean Museum for drawing his attention to a curator's interest in this topic.

Open Access This article is distributed under the terms of the Creative Commons Attribution 4.0 International License (http://creativecommons.org/licenses/by/4.0/), which permits unrestricted use, distribution, and reproduction in any medium, provided you give appropriate credit to the original author(s) and the source, provide a link to the Creative Commons license, and indicate if changes were made.

\section{References}

AECOM \& TEA (2016) Theme Index and Museum Index. AECOM \& TEA, Los Angeles. https://www. aecom.com/theme-index/. Accessed 13 Mar 2018

Biggs D, Holden MH, Braczkowski A, Cook CN, Milner-Gulland EJ, Phelps J, Scholes RJ, Smith RJ, Underwood FM, Adams VM, Allan J, Brink H, Cooney R, Gao Y, Hutton J, Macdonald-Madden E, Maron M, Redford KH, Sutherland WJ, Possingham HP (2017) Breaking the deadlock on ivory. Science 358(6369):1378-1381

Braczkowski A, Holden MH, O’Bryan C, Choi CY, Gan X, Beesley N, Gao Y, Allan J, Tyrrell P, Stiles D, Brehony P, Meney R, Brink H, Takashina N, Lin MC, Lin HY, Rust N, Salmo SG III, Watson 
JEM, Kahumbu P, Maron M, Possingham HP, Biggs D (2018) Reach and messages of the world' largest ivory burn. Conserv Biol. https://doi.org/10.1111/cobi.13097

Brewer C (2001) Cultivating conservation literacy: "Trickle down" education is not enough. Conserv Biol 15(5):1203-1205

Bride I (2006) The conundrum of conservation education and the conservation mission. Conserv Biol 20(5):1337-1339

British Museum Annual Reports and Account (2016-2017) London. http://www.britishmuseum.org/ about_us/management/annual_reports_and_accounts.aspx. Accessed Mar 2018

British Museum Annual Review (2017-2018) https://www.britishmuseum.org/pdf/The\%20British\%20 Museum_Annual\%20Review\%202017_18_text\%20pages_v10_lowres.pdf. Accessed Nov 2018

Burk JL (2018) The display of Baroque ivories in the Bayerisches National Museum from the Foundation of the Museum in 1855 to the present (2018). Curator 61(1):223-245

Cameron FR (2007) Moral lessons and reforming agendas: history museums, science museums, contentious topics and contemporary societies. In: Knell S, Macleod S (eds) Museum Revolutions. Routledge, London, pp 330-342

Cameron FR, Hodge B, Salazar JF (2013) Representing climate change in museum space and places. Wiley Interdiscip Rev Clim Change 4(1):9-21

Carter LB (2017) Reducing demand for ivory in China: a qualitative and quantitative study. Doctoral dissertation

Castranova S, La Ferla A (2018) Walking with elephants: stories of ivories in a museum of ancient art. Curator. https://doi.org/10.1111/cura.12239

Chang E (2006) Interactive experiences and contextual learning in museums. Stud Art Educ 47(2): $170-186$

Chase MJ, Schlossberg S, Griffin CR, Bouché JC, Djene SW, Elkan PW, Ferreira S, Grossman F, Kohi EM, Landen K, Omondi P, Peltier A, Selier JSA, Sutcliffe R (2016) Continent-wide survey reveals massive decline in African savannah elephants. PeerJ. https://doi.org/10.7717/peerj.2354

Cohen O, Heinecke A (2018) Dialogue exhibitions: putting transformative learning theory into practice. Curator. https://doi.org/10.1111/cura.12254

Cole JB (2018) Historical ivory arts and the protection of contemporary wildlife. Curator 61(1):17-33

Curnow K (2018) Ivory as cultural document: the crushing burden of conservation. Curator 61(1):61-94

Daxue Consulting (2017) Social media: high culture's new advertisement front for Chinese museum visitors. Daxue Consulting, Shanghai. http://daxueconsulting.com/chinese-museum-visitors/. Accessed Apr 2018

De Boer WF, Langevelde FV, Prins HHT, Ruiter PCD, Blanc J, Vis MJP, Gaston KJ, Hamilton ID (2013) Understanding spatial differences in African elephant densities and occurances, a continent-wide analysis. Biol Conserv 159:468-476

Dirzo R, Young HS, Galetti M, Ceballos G, Isaac NJB, Collen B (2014) Defaunation in the Anthropocene. Science 345(6195):401-406

Dodgeson M (quoted in Davidson) (2017) How would a total ban affect ivory antiques? https://edition.cnn. com/style/article/antique-ivory-debate-uk/index.html. Accessed 10 Mar 2018.

Dorfman EJ (2018) Elephants and ivory: coordinating natural history museum action to address wildlife crime. Curator 61(1):133-145

Edson G (2009) Practical ethics and the contemporary museum. Museol Q 23(1):5-24

Environmental Investigation Agency (2017) https://eia-international.org/uk-largest-supplier-world s-ivory-markets/. Accessed Nov 2018

Gazi A (2014) Exhibition ethics—an overview of major issues. J Conserv Mus Stud 10:100. https://doi. org/10.5334/jcms. 1021213

Goldstein L, Kintigh K (1990) Ethics and the reburial controversy. Am Antiq 55(3):585-591

Gusset M, Dick G (2011) The global reach of zoos and aquariums in visitor numbers and conservation expenditures. Zoo Biol 30(5):566-569

IFAW (2017) UK ivory surrender launched to protect elephants. https://www.ifaw.org/united-kingdom/ news/uk-ivory-surrender-launched-protect-elephants. Accessed May 2018

International Council of Museums (ICOM) (2004) Code of ethics. ICOM, Paris. http://archives.icom. museum/ethics.html. Accessed Apr 2018

IUCN (2018) Elephas maximus (Asian Elephant). https://www.iucnredlist.org/species/7140/12828813. Accessed 5 Mar 2018. Loxondonta africana (African Elephant). https://www.iucnredlist.org/speci es/12392/3339343. Accessed 5 Mar 2018

Jennings R (2018) China will remain an elephant in the room even after its ivory ban. Forbes Report, Jersey City. https://www.forbes.com/sites/ralphjennings/2018/01/05/china-will-remain-an-elephant-in-theroom-even-after-its-ivory-ban/\#6e3fdecf53d3. Accessed Apr 2018 
Jepson P, Canney S (2003) Values-led conservation. Glob Ecol Biogeogr 12(4):271-274

Kilmister H (2003) Visitor perceptions of ancient Egyptian human remains in three United Kingdom museums. Pap Inst Archaeol 14:57-69. https://doi.org/10.5334/pia.202

Kramer R, Sawyer R, Amato S, LaFontaine P (2017) The elephant ivory market: a new baseline. https:// www.traffic.org/site/assets/files/1378/traffic_us_ivory_report_2017.pdf. Accessed Apr 2018

Kurin R, Ashe D (2018) Elephants and their ivory: zoos and museums. Curator 61(1):43-46

Lauffenburger J, Drayman-Weisser T (2018) Teaching Ivory 101: building on a legacy at the Walters Art Museum. Curator 61(1):111-132

Lemieux AM, Clarke RV (2009) The international ban on ivory sales and its effects on elephant poaching in Africa. Br J Criminol 49(4):451-471

Levy MP (2018) Works of art and ivory: what are the issues? Curator 61(1):47-60

Libbey P (2017) Met defends suggestive painting of girl after petition calls for its removal. New York Times, New York. https://www.nytimes.com/2017/12/04/arts/met-museum-balthus-painting-girl.html. Accessed Mar 2018

Malhi Y, Doughty CE, Galetti M, Smith FA, Svenning JC, Terborgh JW (2016) Megafauna and ecosystem function from the Pleistocene to the Anthropocene. Proc Natl Acad Sci USA 113(4):838-846

Met Museum Press (2017) Met museum welcomes 7 million visitors. Met Museum Press, New York, July 17. https://www.metmuseum.org/press/news/2017/2017-annual-attendance. Accessed Mar 2018

Milner-Gulland EJ, Beddington JR (1993) The exploitation of elephants for the ivory trade: an historical perspective. Proc R Soc Lond B 252(1333):29-37

Morrison S (2014) Prince William wants 'All royal ivory destroyed'. Independent, London, February 16. http://www.independent.co.uk/environment/nature/prince-william-wants-all-royal-ivory-destroyed9131140.html. Accessed Mar 2018

Moss A, Esson M (2013) The educational claims of zoos: where do we go from here? Zoo Biol 32(1):13-18

Museums Association (MA) (2008) Code of ethics for museums. Museums Association, London. http:// www.museumsassociation.org/download?id=15717. Accessed Apr 2018

Notice of the General Office of the State Council on Orderly Stopping Commercial Activities of Processing and Sales of Ivory and Products (2016) http://en.pkulaw.cn/display.aspx?cgid=287802\&lib=law. Accessed Nov 2018

Scanlon J (2018) Wildlife trafficking and how museums can help. Curator 61(1):11-16

Somerville K (2016) Ivory: power and poaching in Africa. Hurst \& Company, London

Stiles D, Martin R, Moyle B (2016) Analysis of ivory demand drivers. http://danstiles.org/publications/ivory 143.Analysis\%20of\%20Demand.pdf. Accessed 10 Jan 2019

Terborgh J, Estes JA (2010) In: Terborgh J, Estes JA (eds) Trophic cascades: predators, prey, and the changing dynamics of nature. Island Press, Washington, DC

Thouless C, Dublin HT, Blanc JJ, Skinner DP, Daniel TE, Taylor F, Maisels F, Frederick L, Bouché P (2016) African Elephant Status Report 2016. Occasional Paper Series of the IUCN Species Survival Commission 60

Vigne L, Martin E (2017) Decline in the legal ivory trade in China in anticipation of a ban. Save the Elephants. http://www.savetheelephants.org/wp-content/uploads/2017/03/2017_Decline-in-legal-Ivory -trade-China.pdf. Accessed 8 Feb 2018

Vollrath F, Ruixin M, Shah DU (2018) Ivory as an important model bio-composite. Curator 61(1):95-110

Walker JF (2009) Ivory's ghosts: The white gold of history and the fate of elephants. Atlantic Monthly Press, New York

Wittemyer G (2016) Illegal wildlife trade: look to the elephants. Science 353(6307):1507

Wittemyer G, Northrip JM, Blanc J, Douglas-Hamilton I, Omondi P, Burnham KP (2014) Illegal killing for ivory drives global decline in African elephants. Proc Natl Acad Sci USA 111(36):13117-13121

Wyner Y, Desalle R (2010) Taking the conservation biology perspective to secondary school classrooms. Conserv Biol 24(3):649-654

Young A, Khalil KA, Wharton J (2018) Empathy for animals: a review of the existing literature. Curator. https://doi.org/10.1111/cura.12239

Zhou X, Wang Q, Zhang W, Jin Y, Wang Z, Chai Z, Zhou Z, Cui X, MacMillan DC (2018) Elephant poaching and the ivory trade: the impact of demand reduction and enforcement efforts by China from 20052017. Glob Ecol Conserv 16:e0486

Publisher's Note Springer Nature remains neutral with regard to jurisdictional claims in published maps and institutional affiliations. 